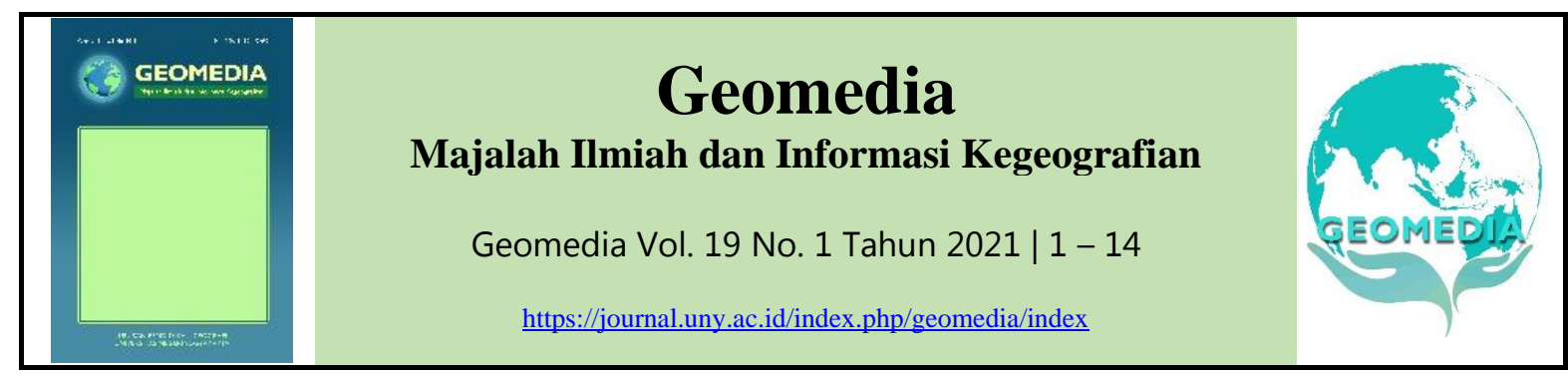

\title{
Kerentanan spasial air tanah terhadap pencemaran metode GOD pada formasi batugamping koral Kota Saumlaki, Maluku
}

\author{
Erik Febriarta ${ }^{a, b} 1^{*}$, Bayu Argadyanto Prabawa ${ }^{c, 2}$, Ajeng Larasati ${ }^{a, b} 3$ \\ a Magister Pengelolaan Pesisir dan Daerah Aliran Sungai, Fakultas Geografi, Universitas Gadjah Mada, DIY, Indonesia \\ b Palwa Karya, www.palawakarya.co.id, Daerah Istimewa Yogyakarta, Indonesia \\ c Prodi Perencanaan Wilayah dan Kota, Fakultas Sains dan Teknologi, Universitas Teknologi Yogyakarta, DIY, Indonesia
}

1 e.febriarta@gmail.com *; ${ }^{2}$ bayuargadyanto@gmail.com, ${ }^{3}$ ajlarasati@gmail.com

*korespondensi penulis

\begin{tabular}{ll}
\hline Informasi artikel \\
\hline Sejarah artikel & \\
Diterima & $: 07$ Januari 2021 \\
Revisi & $: 23$ Maret 2021 \\
Dipublikasikan & $: 31$ Mei 2021 \\
\hline
\end{tabular}

Kata kunci:

Air tanah

Batugamping

GOD

Kerentaan

Pencemaran

\begin{abstract}
A B S T R A K
Kota Saumlaki merupakan ibu kota Kabupaten Maluku Tenggara Barat, yang secara geografis berada di ujung Pulau Yamdena bagian selatan merupakan bagian dari Pusat Kegiatan Strategis Nasional (PKSN) Saumlaki di Provinsi Maluku. Kota Saumlaki juga menjadi pusat pemerintahan dan memiliki laju pertumbuhan penduduk meningkat dan pembangunan yang semakin intensif. Untuk menjaga kerberlangsungan sumber daya air perlu ditinjau dari sisi faktor lingkungan (geologi) dari sifat batuan terhadap kerentanan pencemaran. Untuk mengetahui hal tersebut maka tujuan dari penelitian ini adalah mengetahui potensi kerentanan air tanah terhadap pencemaran pada batugamping koral dengan pedekatan GOD di Kota Saumlaki. Kerentanan GOD didasarkan atas sifat batuan dalam meloloskan air tanah yaitu, tipe akuifer $(G)$, litologi akuifer $(O)$ dan kedalaman tinggi muka air (D). Hasil penilaian menunjukkan dua (2) kelas, yaitu kerentanan tinggi dan kerentanan ekstrim. Pusat Kota Saumlaki termasuk kerentanan ekstrim yang dipengaruhi oleh kedalaman air tanah yang dangkal, dan sifat batuan yang porus dalam potensi mempercepat mengalirkan pencemaran
\end{abstract}

\section{A B S T R A C T}

\section{Keywords:}

GOD

Groundwater

Limestone

Pollution

Vulnerability
Saumlaki, the capital city of Maluku Tenggara Barat Regency, is geographically located at the southern tip of Yamdena Island and is part of the Saumlaki National Strategic Activities Center (PKSN) in Maluku Province. As a strategic area and government center, it is faced with accelerating population growth and increasingly intensive development. Maintaining water resource sustainability means investigating environmental (geological) factors that underlie rock properties and their consequence on groundwater vulnerability to pollution. In line with this, the research was designed to determine potential groundwater vulnerability in coral limestone area in Saumlaki through the GOD approach which associates vulnerability to transmissivity (the nature of rocks to transmit water) as a function of aquifer type $(\mathrm{G})$, aquifer lithology (O), and depth to water table (D). The measurement results showed two vulnerability classes: high and extreme. The city center's groundwater is extremely vulnerable due to shallow depth to groundwater and porous rocks, potentially accelerating pollution spread. 


\section{Pendahuluan}

Kebutuhan dasar hidup manusia tidak lepas dari keterdapatan atau ketersediaan air (air baku). Definisi air menurut BSN (2002) adalah semua air yang terdapat di dalam dan berasal dari sumbersumber air, baik yang terdapat di atas maupun di bawah permukaan tanah, tidak termasuk dalam pengertian ini yaitu terdapat di laut. Fungsi utama air adalah sebagai kebutuhan dasar atau kebutuhan domestik (kebutuhan rumah tangga) dan akan semakin meningkat sejalan dengan pertambahan jumlah penduduk dan perkembangan sebuah wilayah atau kawasan (DPU, 1996; Febriarta et al., 2018; Setyaningrum \& Febriarta, 2019). Keberadaan air tanah sangat dipengaruhi oleh kondisi geologi. Singhal \& Gupta (2010) menjelaskan bahwa kondisi keterdapatan air tanah sangat dipengaruhi oleh sifat batuan dalam menahan dan melolosakan air. Keterdapatan air tanah sangat dipengaruhi oleh sifat hidrogeologi yaitu kondisi batuan (litologi) dengan material lepas-lepas tidak kompak, dan media percelahan berupa lubang antar butir dengan ukuran sedang-kasar (akuifer) (Fetter, 2014).

Kota Saumlaki merupakan daerah dengan morfologi bergelombang dengan batuan dasar yang tersusun atas formasi batugamping koral (KESDM, 2015a). Secara geologi regional Kota Saumlaki (Pulau Yamena) terbentuk akibat gaya tektogenisis dari pergerakan Busur Banda bagian dari pergerakan subdaksi (tumbukan) lempeng Australia kearah utara (Sukardi \& Sutrisno, 1989). Bersamaan dengan fase tektonik terjadi pengangkatan perairan dangkal yang menghasilkan sesar ikutan dan kekar. Secara geologi regional, hasil dari pergerakan tektonik, maka terbentuk wilayah batuan kompleks yaitu batugamping koral (Qs) (KESDM, 2012; Sukardi \& Sutrisno, 1989). Kondsi batuan batugamping koral memiliki tingkat kerentanan air tanah terhadap pencemaran yang dipengaruhi oleh media aliran berupa celah hingga pelarutan yang mempercepatat pencemaran (Uhlemann et al., 2017). Abdelmadjid \& Omar (2013) juga menyebutkan bahwa daerah dengan penyusun batugamping diperlukan pemetaan kerentanan air tanah terhadap pencemaran sebagai langkah strategis dalam pengelolaan sumber daya air.

\section{Kondisi Geologi}

Kenampakan struktur geologi di Kota Saumlaki dipengaruhi oleh pengangkatan busur banda yang merupakan akibat pertemuan dasar lempeng benua Australia dengan arah utara terhadap lempeng Asia. Sehingga struktur di sekitar Kota Saumlaki yang berkembang sangat dipengaruhi oleh kondisi struktur. Arah struktur yang berkembang dengan arah utara-selatan dan barat-timur (Sukardi \& Sutrisno, 1989). Kenampakan struktur geologi berupa lipatan, sesar dan kelurusan dengan arah utara-selatan, baratdaya-timurlaut. Kondisi geologi regional secara umum tersusun atas dua (2) formasi batuan yaitu Formasi Saumlaki (Qs) yang mendominasi penysusun batuan dan Formasi Batilembuti (QTb) yang berada di bagian utara dan sebagian pesisir bagian timur. KESDM (2012) dan Sukardi \& Sutrisno (1989) menyebutkan bahwa Formasi Saumlaki (Qs) tersusun atas batugamping koral, padat, setempat terbreksikan bagian bawah konglomerat, dengan komponen batugamping dan cangkang fosil. Sedangkan Formasi Batilembuti (QTb) tersusun atas batu napal yang kaya akan fosil plangton dan bentos, batugamping yang sangat rapi, yang terbentuk seluruhnya dari fosil plangton dan bentos, napal kapuran pewarna putih dan ringan. Kondisi spasial kondisi geologi disajikan pada Gambar 1.

Secara umum penyusun batuan sedimen berupa batugamping memiliki potensi air tanah yang tinggi dengan karakteristik potensi menyimpan atau menahan air tanah kecil atau rendah dan potensi untuk mengalirkan air tanah (kelulusan) tinggi (Febriarta et al., 2015; Febriarta \& Larasati, 2020; Telford et al., 1990; Todd \& Mays, 2005). Dengan karakteristik tersebut, wilayah dengan kondisi batugamping dengan media aliran bercelah dapat berkurang air tanahnya pada musim kemarau, dan bersifat melimpah (surplus) pada musim penghujan dengan kondisi kualitas air yang menurun yang diakibatkan aliran permukaan (runoff) membawa segala material diatas permukaan masuk kedalam tanah tanpa tersaring (filter dari setiap lapisan batuan) (Febriarta \& Widyastuti, 2020; Singhal \& Gupta, 2010). 


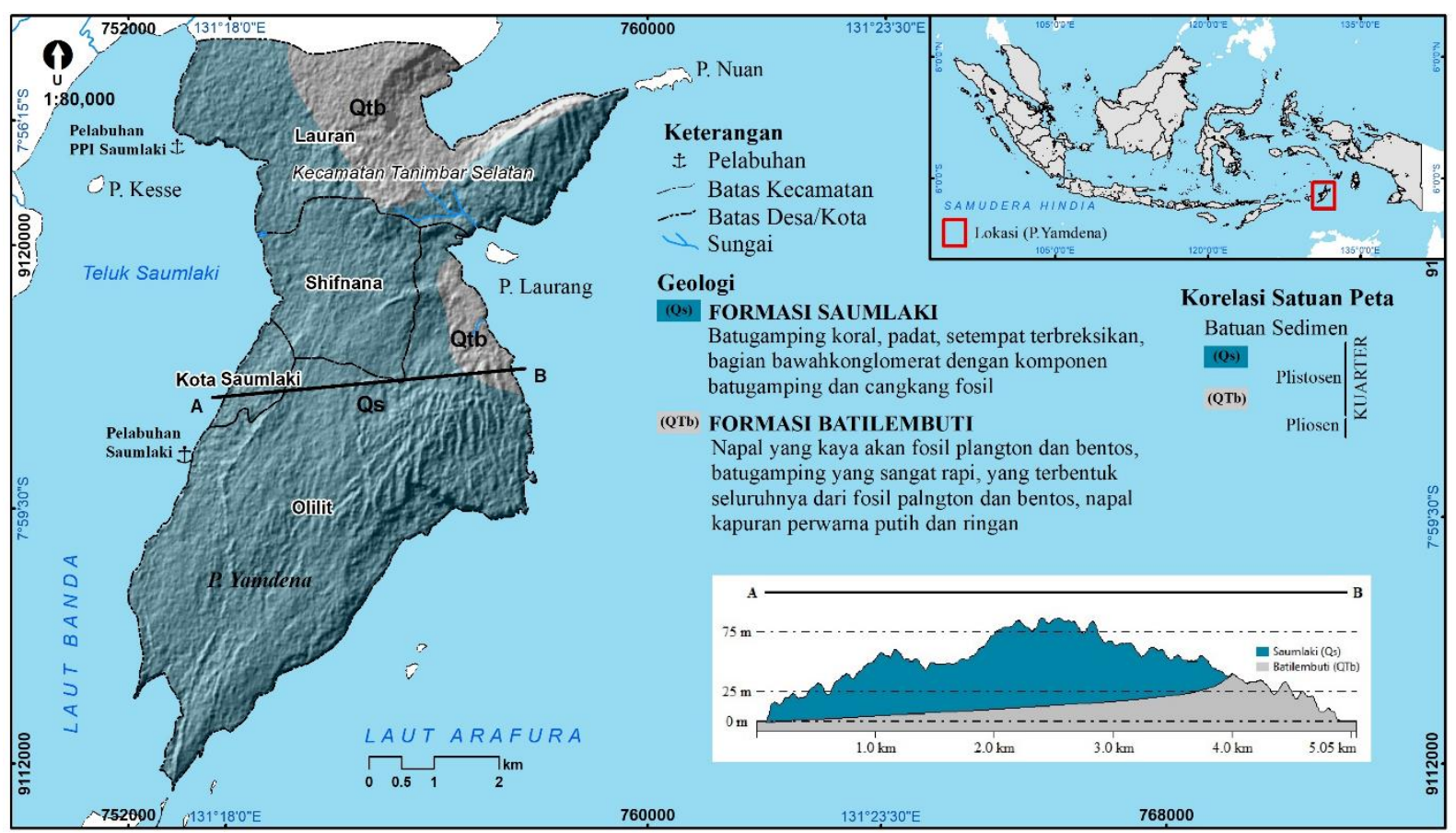

Gambar 1. Kondisi Geologi Regional Kota Saumlaki berada di atas Batugamping Koral bagian dari Formasi Saumlaki (Qs) (KESDM, 2012; Sukardi \& Sutrisno, 1989)

\section{Kondisi Hidrogeologi}

Kondisi hidrogeologi atau dinamika mengenai air bawah tanah yang saling berhubungan dengan keterdapatanya, distribusi penyebaran, pengaliran, polusi dan sifat kimia air bawah tanah (BSN, 2002). ESDM (1995) menyebutkan bahwa daerah penelitian memiliki tiga (3) karakteritik produktivitas air tanah. Zona produktivitas sedang (sedang-tinggi) terdapat pada morfologi dataran pantai hingga daerah bergelombang yang mendominasi di Kota Saumlaki seluas $33,63 \mathrm{~km}^{2}$ atau $80 \%$ dari luas wilayah penelitian, zona dengan produktivitas setempat berada di sebagian daerah dengan morfologi perbukitan dan dataran pantai bagian timur laut dari Kota Saumlaki seluas $5,21 \mathrm{~km}^{2}$ atau $12,43 \%$ luas wilayah penelitain. Produktivitas kecil setempat terdapat di utara zona produktivitas setempat (utara Desa Lauran) (Gambar 2) dengan morfologi perbukian dan dataran pantai yang terdapat di timur laut Kota Saumlaki.

Pada zona produktivitas sedang, memiliki sistem akuifer celah, rekahan dan saluran pelarutan dengan keterusan ( $\mathrm{T}$ ) sedang dan potensi debit $>10 \mathrm{l} /$ detik (ESDM, 1995). Wilayah produktivitas sedang berada pada litologi akuifer batugamping, yang tersusun atas batugamping koral, padat, setempat terbreksikan dengan potensi kelulusan (K) sedang-tinggi. Zona pada produktivitas setmpat, memeliki karakteritik dengan sistem akuifer berupa celah, rekahan dan saluran pelarutan dengan nilai keterusan (T) rendah-sedang, potensi debit $<5$ l/detik, sedangkan pada produktivitas kecil setempat sistem akuifer berupa celah atau sarang dengan keterusan $(T)$ rendah dan debit air langka (KESDM, 2015a, 2015b). Zona produktivitas setempat dan kecil berada pada formasi batuan padu dengan kelulusan (K) yang rendah (Gambar 2). Pada zona produktivitas kecil stempat, berada pada formasi batuan padu yang tersusun atas perselingan batugamping pasiran, napal dan batupasir gampingan memiliki debit yang langka hingga tidak ada (KESDM, 2015a).

Sumber daya air yang paling banyak untuk dimanfaatkan berasal dari air tanah. Keuntungan pemanfaatan air tanah adalah suplai atau ketersediaanya relatif besar (menerus), terlindungi oleh lapisan kedap dari aktivitas di atas pemukaan, kondisi air terendapkan dan tersaring oleh batuan yang dilewati menjadi lebih jernih (Kohfahl et al., 2019; Todd \& Mays, 2005). 


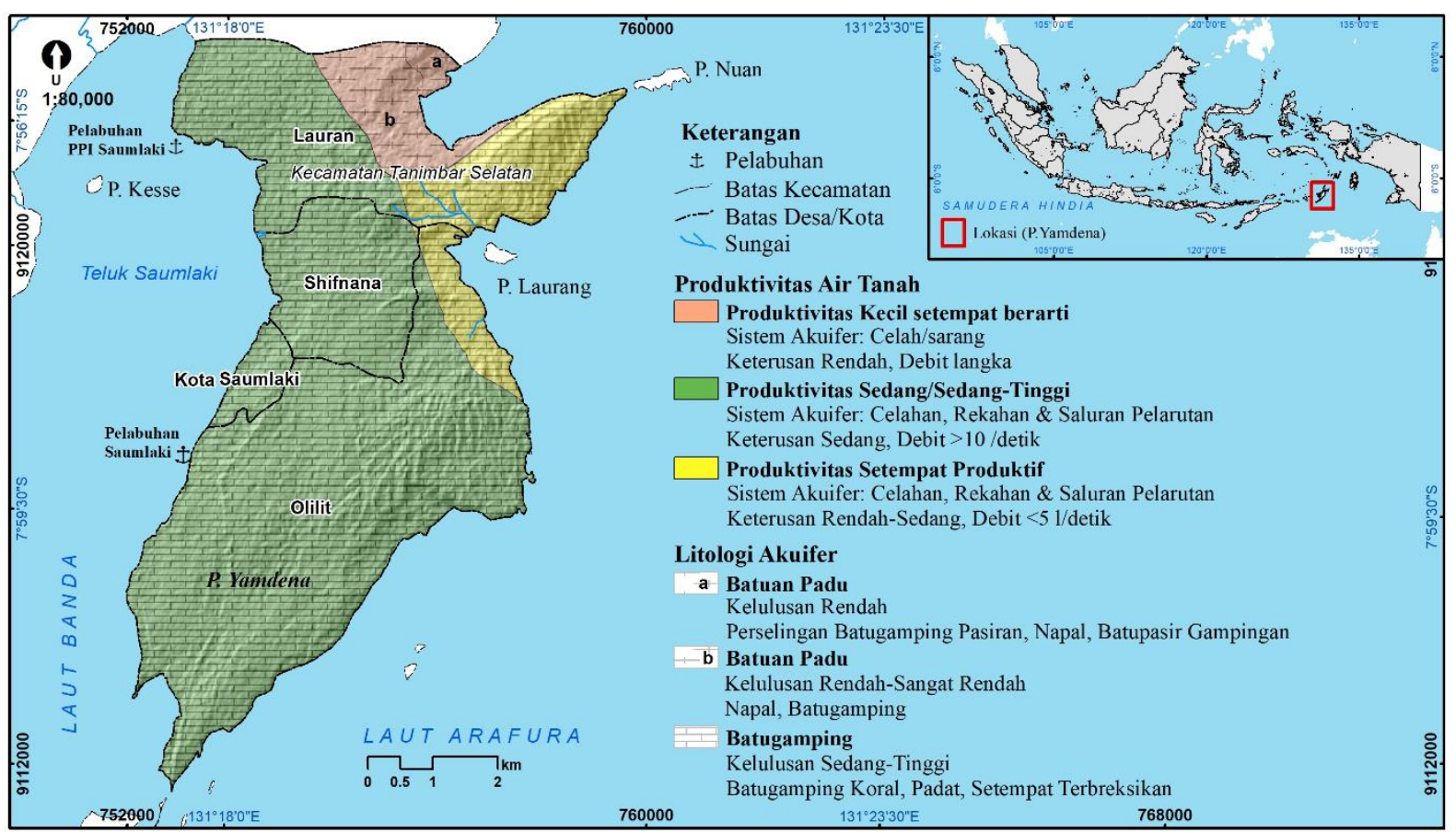

Gambar 2. Kondisi Hidrogeologi Kota Saumlaki didominasi dengan Produktivitas Sedang (KESDM, 2015a, 2015b; PUPR, 2016; Sukardi \& Sutrisno, 1989)

Kekuangan dari pemanfaatan air tanah antara lain: eksplorasi untuk mendapatkan air tanah memerlukan pengeboran di daerah batuan padu, sehingga memerlukan biaya yang tinggi, dipengaruhi oleh faktor geologi (sifat batuan pembawa air tanah) suplai dan keterusan (T) keterdapatan air tanah sangat dipengruhi oleh zona tangkapan air tanah di daerah hulu dan bila terjadi kontaminasi dapat cepat tercemar dalam satu sistem (Febriarta \& Larasati, 2020; Febriarta \& Oktama, 2020; Vrba \& Zaporozec, 1994).

Kondisi penurunan kualitas air tanah secara kondisi fisik dari penyusun batuan dapat dikatagorikan sebagai kerentanan (Ciemens et al., 2020; Febriarta et al., 2020). Kerentanan air tanah merupakan kondisi masuknya unsur satuan, komponen fisika, kimia atau biologi ke dalam air bawah tanah dan/atau berubahnya tatanan air bawah tanah oleh kegiatan manusia oleh proses alami yang mengakibatkan mutu air bawah tanah turun sampai ke tingkat tertentu sehingga tidak lagi sesuai dengan peruntukannya (Akhtar et al., 2020; BSN, 2012). Penilaian kerentanan air tanah memerlukan pendekatan sistematik empiris dikarenakan tidak dapat diidentifikasi secara langsung secara kenampakan fisik (visual) (Guettaia et al., 2017; Vienastra \& Febriarta, 2018). Rathinasamy et al., (2019) menyebutkan bahwa perlu pendekatan parameter akuifer, yaitu kondisi batuan melolosakan air tanah dalam melihat kecepatan potensi penyebaran sumber pencemar. Seperti yang dijelaskan oleh Ciemens et al., (2020), bahwa kondsi kedalaman tinggi muka air (akuifer) yang dangkal, tekstur tanah permukaan yang porus dan batuan berpori mempunyai potensi mengalirkan pencemaran lebih cepat dibandingkan pada kondisi lingkungan dengan batuan padu. Untuk mengetahui potensi pencemaran dapat diketahui dengan penilian sifat batuan dalam mempercepat pencemaran air tanah (Putranto, 2019)

Pendekatan metode kerentanan air tanah DRASTIC dikembangkan oleh Aller et al., (1987) merupakan metode yang paling populer dengan multi kriteria parameter akuifer dengan keunggulan nilai rentang kerentanan yang panjang, sehingga dapat mengidentifikasi kerentanan lebih rendah dan tidak terfokuskan pada potensi risiko pencemaran, tetapi memiliki kekurangan dari ketersediaan data yang sangat banyak. Kota Saumlaki hingga saat ini belum memiliki ketersediaan yang lengkap untuk pemodekan kerentanan air tanah terhadap pencemaran tersebut. Pendekatan yang dimungkinkan untuk pemodelan keruangan (spasial) kerentanan air tanah terhadap pencemaran pada batugamping koral yaitu metode GOD. Pemilihan penilaian kerentanan metode GOD memiliki kesesuaian untuk analisis pencemaran pada akuifer bebas, dan dapat 
memetakan kerentanan dalam akuifer karbonat karstifikasi pada skala kecil hingga sedang (Foster, 1987; Linggasari et al., 2019; Purnama \& Cahyadi, 2019; Siswoyo, 2018). Karakteristik tersebut sesuai dengan kondisi lingkungan Kota Saumlaki dan sekitarnya (Pulau Yamdena). Kawasan tersebut juga merupakan bagian dari Kawasan Bentang Alam Karst (KBAK) Maluku Tenggara yang merupakan bagian dari akuifer karbonat (KESDM, 2018b; Permen ESDM, 2012). Sehingga tujuan dari penelitian ini adalah mengetahui zona kerentanan air tanah terhadap pencemaran pada formasi batuan batugamping koral (Qs) dengan metode GOD di Kota Saumlaki (Pulau Yamdena), Kecamatan Tanimbar Selatan, Kabupaten Maluku Tenggara Barat (Gambar 3).

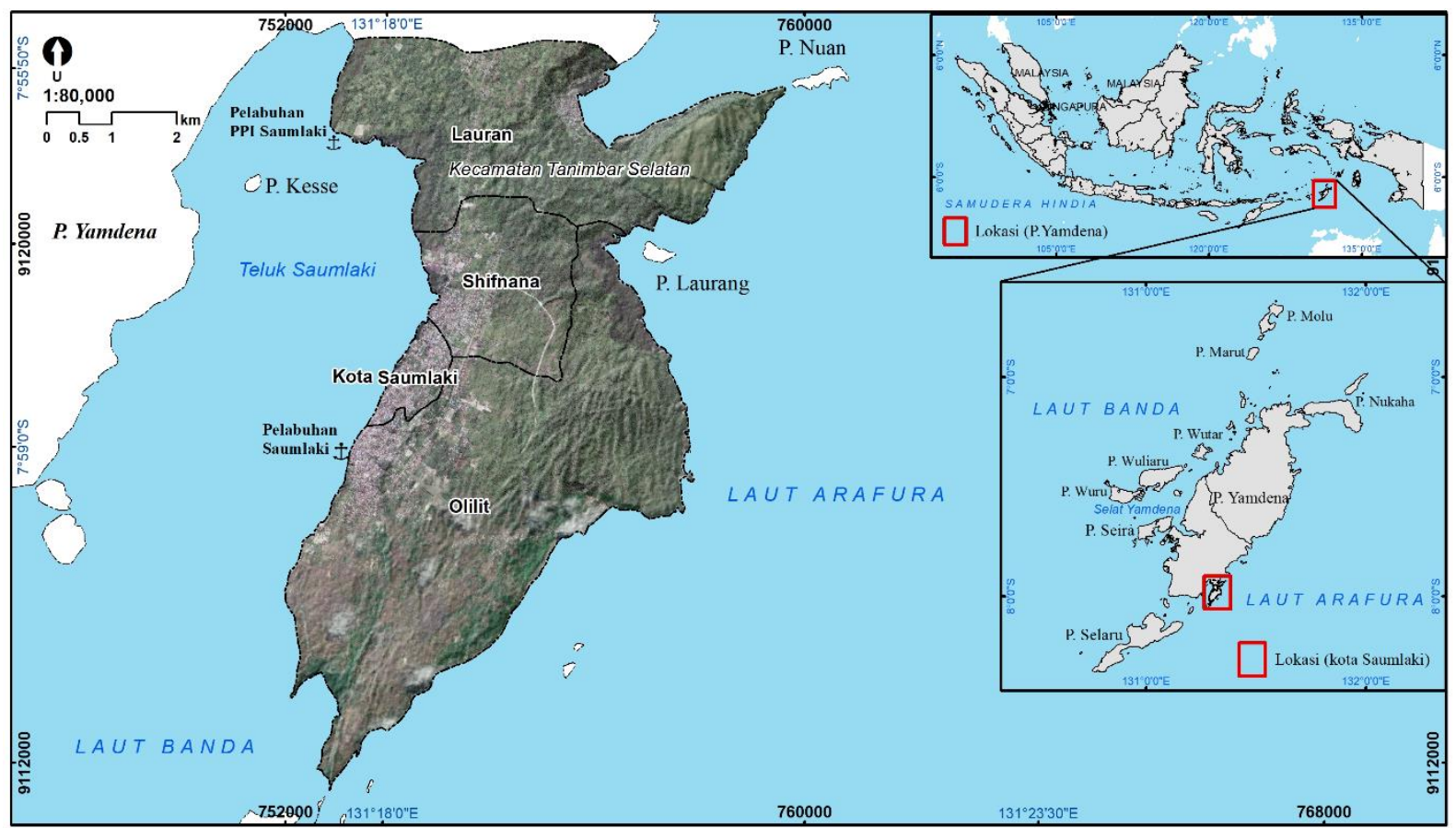

Gambar 3. Lokasi Penelitian (Kota Saumlaki, Kecamatan Tanimbar Selatan, Kabupaten Maluku Tenggara Barat).

\section{Metode}

\section{Lokasi Penelitian}

Lokasi penelitian berada di Kecamatan Tanimbar Selatan, Kabupten Kepulauan Tanimbar, Provinsi Maluku. Lokasi penelitiam kerentanan air tanah terhadap pencemaran berada di wilayah perkotaan di Kecamatan Tanimbar selatan dengan ibu di Kota Saumlaki Secara geografis berada di garis lintang dan bujur $-7.926911^{\circ}$ hingga $8.031733^{\circ}$ LS dan $131.285707^{\circ}$ hingga $131.360478^{\circ}$ BT.

Wilayah penelitian merupakan daerah pesisir yang secara administrasi terdiri atas Kelurahan (Kota) Saumlaki $\left(1,03 \mathrm{~km}^{2}\right)$, Desa Olilit $\left(22,91 \mathrm{~km}^{2}\right)$, Desa Sifnana $\left(5,20 \mathrm{~km}^{2}\right)$ dan Desa Lauran $(12,76$ $\mathrm{km}^{2}$ ). Batas wilayah sebelah utara berbatasan dengan Desa Bomaki Kecamatan Tanimbar Selatan, sebelah barat berbatasan dengan Teluk Saumlaki. Batas wilayah sebelah timur berbatasan dengan Laut Arafura dan batas wilayah bagian selatan berbatasan dengan Laut Banda (Gambar 3).

\section{Kerentanan GOD}

Pendekatan yang digunakan untuk penilaian indek kerentanan air tanah terhadap kerentanan terhadap pencemaran menggunakan metode GOD. Metode GOD merupakan analisis kerentanan air tanah dengan pemodelan numberik menghasilkan nilai indek kerentanan yang dikembangkan oleh Foster pada tahun 1987 (Ferreira et al., 2004; Foster, 1987). Metode GOD terdiri atas penilaian kerentanan dengan pendekatan tiga (3) parameter, yaitu G (Groundwater occurrence) atau kondisi keberadaan air tanah, O (Overall lithology of aquifer or aquitard) atau kondisi litologi akuifer atau akuitar secara keseluruhan, dan D (Depth to groundwater table) atau kedalaman muka air tanah. 
Penelitian kerentanan air tanah terhadap pencemaran menggunakan data primer untuk paramter kedalaman muka air tanah (D). Pengukuran tinggi muka air tanah menggunakan pita ukur dari permukaan hingga kondisi muka air tanah dengan satuan pengukuran meter (m) dengan pencatatan lokasi koordinat pengukuran. Pengamatan dan pengukuran kedalaman muka air tanah diukur di sumur gali. Data tipe akuifer (G) diperoleh dari data sekunder dari badan geologi, pusat survei geologi (KESDM, 2012, 2015a, 2015b). Sedangkan dan litologi akuifer $(\mathrm{O})$ diperoleh dari data sekunder dari badan geologi, pusat survei geologi (KESDM, 2015a, 2015b) (Tabel 1). Penilaian karakteristik pada setiap parameter didasarkan atas nilai skor indek yang disajikan pada Gambar 4.

Analisis keruangan (spasial) nilai kedalaman air tanah diolah dengan sistem informasi geografis (SIG) dengan metode interpolasi. Pendekatan untuk memperoleh nilai garis kontur kedalaman air tanah dengan metode kriging. Metode kriging sesuai digunkan untuk interpolasi kontur kedalaman air tanah karena menghasilkan nilai simpangan mean yang kecil dengan hasil inetrpolasi yang merata disekitar data populasi seperti yang disajikan pada Gambar 4.

Tabel 1. Sumber Data

\begin{tabular}{lll}
\hline \multicolumn{1}{c}{ Data } & \multicolumn{1}{c}{ Parameter } & \multicolumn{1}{c}{ Sumber Data } \\
\hline (G) Keberadaan air tanah & Tipe/jenis akuifer & KESDM, 2012; 2015a; 2018a \\
(O) Litologi akuifer & Litologi/batuan penyusun & KESDM, 2015a; 2015b \\
$\begin{array}{ll}\text { (D) Kedalaman muka air tanah } \\
\text { Kualitas air tanah }\end{array}$ & Tinggi muka air tanah (m) & $\begin{array}{l}\text { Pengukuran lapangan; PUPR, 2016 } \\
\text { PUPR, 2016 }\end{array}$ \\
\hline
\end{tabular}

\section{Sumber: Analisis, 2020}

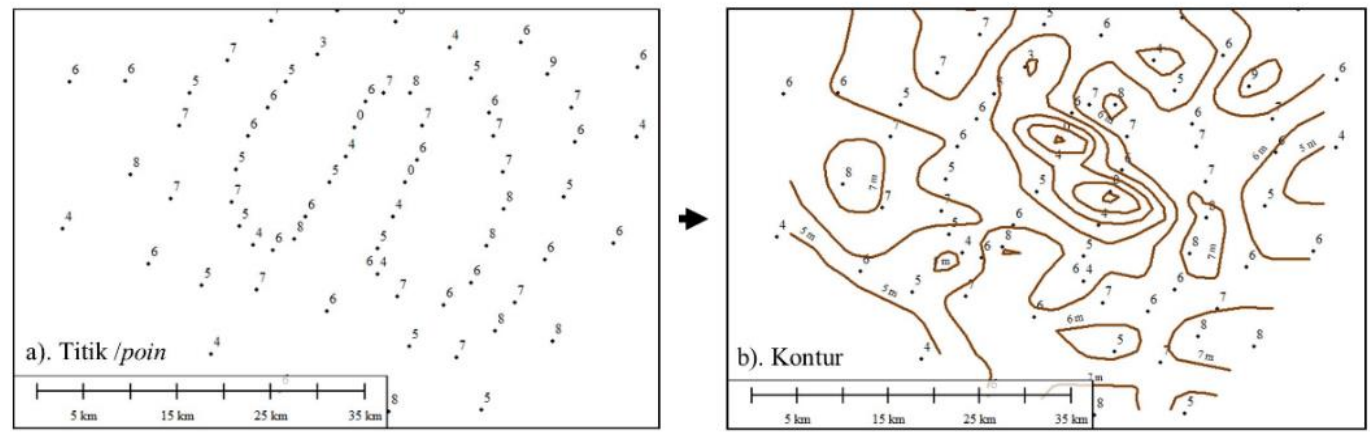

Gambar 4. Interpolasi Data Kedalaman Air Tanah Menjadi Kontur Air Tanah

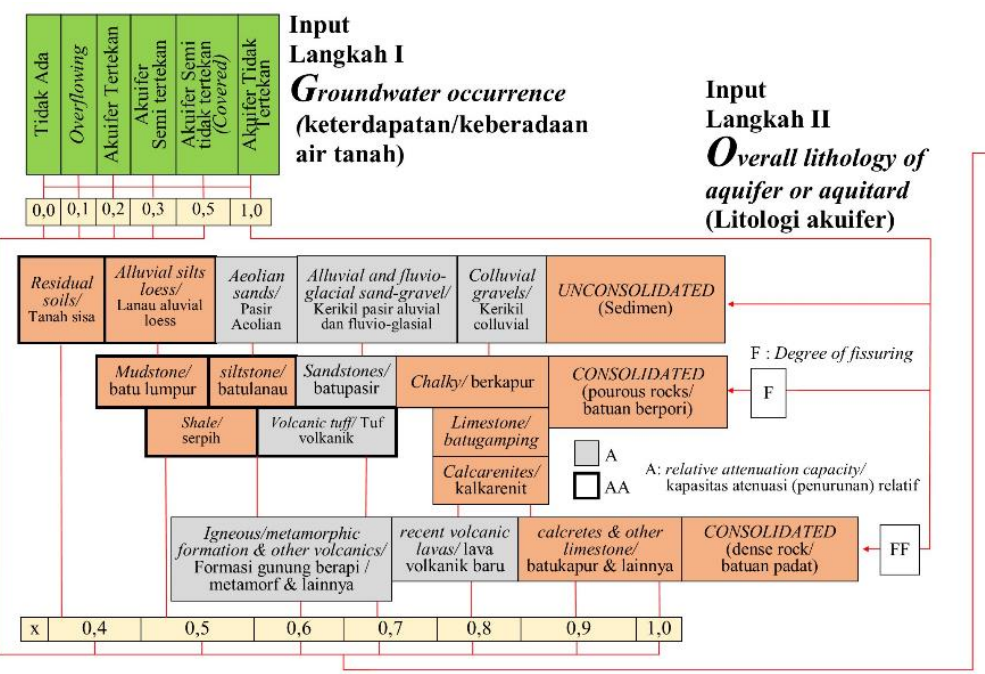

Input

Langkah III

Depth to groundwater table

(Kedalaman muka air tanah)

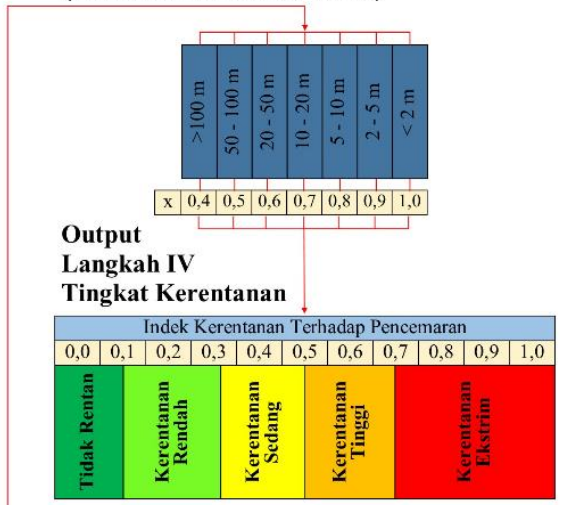

Gambar 5. Sistem empiris GOD kerentanan air tanah (Abdelmadjid \& Omar, 2013; Cahyadi, 2019; Hastuti et al., 2016) 
Hasil dari penilaian setiap parameter kerentanan air tanah menghasilkan nilai indek seperti yang disajikan pada diagram alir output (Gambar 5). Pendekatan rumus yang digunakan untuk menghasilkan nilai indek kerentanan adalah dengan perhitungan linier variabel kerentanan GOD (Foster, 1987; Hastuti et al., 2016), sebagai berikut:

$$
i G O D=G w \times O w \times D w
$$

dimana;

iGOD : nilai indek kerentanan GOD

G,O,D : parameter kerentanan (Gambar 4)

w : weight (nilai bobot)

Analisis tingkat kerentanan air tanah terhadap pencemaran mengacu pada kelas kerentanan (Gambar 5) dengan lima (5) tingkat kerentanan, yaitu tidak rentan, kerentanan rendah, kerentanan sedang, kerentanan tinggi dan kerentanan ekstrim.

\section{Validasi Kerentanan Dengan Kualitas Air Tanah}

Kualitas airtanah diperlukan untuk evaluasi penilaian kerentanan air tanah terhadap pencemaran. Tingkat pencemaran air tanah dapat diketahui dari nilai nitrit $\left(\mathrm{NO}^{2}\right) \quad(\mathrm{mg} / \mathrm{l})$ yang bersumber dari limbah industri dan limbah domestik (Ciemens et al., 2020).

Nilai nitrit $\left(\mathrm{NO}^{2}\right)$ menggunakan hasil laboratorum kualitas air dari Pekerjaan Umum dan Perumahan Rakyat dengan metode uji spektrofotometri (PUPR, 2016). Lokasi sampel nitrit $\left(\mathrm{NO}^{2}\right)$ berjumlah tiga sampel, yaitu $\mathrm{K} 1$ berada di koordinat 756436,06; 9122102,71, lokasi K2 dengan koordinat 754435,58; 9118955,26 dan lokasi K3 berada di koordinat 753373,04; 9117405,03 . Nilai baku mutu nitrit $\left(\mathrm{NO}^{2}\right)$ untuk air minum adalah 10 mg/l (PermenKes, 2010).

\section{Hasil dan pembahasan Jenis Akuifer}

Parameter Groundwater occurrence $(G)$ atau kondisi keberadaan air tanah/tipe akuifer diperoleh dari interpretasi data geologi KESDM (2012) dan KESDM (2015a) (Tabel 2). Interpretasi batasan akuifer menggunakan definisi lapisan batuan jenuh air di bawah permukaan tanah yang dapat menyimpan dan meneruskan air (BSN, 2005). Menurut PUPR (2016) keterdapatan air tanah berada pada kealaman 0-30m yang dipengaruhi oleh kondisi struktur geologi. Berdasarkan kedalaman tersebut, menunjukkan bahwa keterdapatan air tanah relatif dangkal dan bersifat bebas. KESDM (2018b) dan Permen ESDM (2012) menyebutkan bahwa Kota Saumlaki termasuk bagian dari cekungan air tanah (CAT) Saumlaki. Cekungan air tanah (CAT) merupakan wilayah yang dibatasi oleh batas hidrogeologis, tempat semua kejadian hidrogeologis seperti proses pengimbuhan, pengaliran dan pelepasan air tanah berlangsung (BSN, 2005). Berdasarkan definisi tersebut berarti Kota Saumlaki dan sekitarnya (Gambar 3) memiliki potensi air tanah yang luas. KESDM, (2018a) menyebutkan cekungan air tanah (CAT) Saumlaki berada pada penyusun batugamping.

Berdasarkan hasil analisis, diketahui bahwa tipe akuifer yang seragam yaitu akuifer tidak tertekan dengan penysusn batugamping yang tersusun atas batugamping koral, padat, setempat terbreksikan, bagian bawah konglomerat dengan komponen batugamping dan cangkang fosil yang merupakan bagian dari Formasi Saumlaki (Qs) dan Formasi Batilembuti (QTb) dengan marl atau batulumpur dengan batuan penyusun napal yang kaya akan fosil plangton dan bentos, batugamping yang sangat rapi, yang terbentuk seluruhnya dari fosil plangton dan bentos, napal kapuran perwarna putih dan ringan. Berdasarkan karakteristik tersebut dan tidak terdapat lapisan kedap air, dapat dikatagorikan sebagai tipe akuifer tidak tertekan (Fetter, 2014; Milsom, 2003; PUPR, 2016). Penilaian parameter jenis akuifer (tipe akuifer) sebesar 1,0 seperti yang disajikan pada Tabel 3 dan secara keruangan (spasial) disajikan pada Gambar 6a. Nilai tersebut termasuk kelas kerentanan yang tinggi, hal tersebut dipengaruhi oleh sifat akuifer bebas dapat menyebarkan sumber polutan kedalam ait tanah cepat tercampur di dalam sistem akuifer (Febriarta et al., 2020)

Tabel 2. Penilaian Jenis Akuifer (G)

\begin{tabular}{lllc}
\hline \multicolumn{1}{c}{ Formasi } & \multicolumn{1}{c}{ Batuan } & \multicolumn{1}{c}{ Tipe Akuifer } & Nilai/Skor \\
\hline Saumlaki (Qs) & Batugamping koral & Akuifer tidak tertekan & 1,0 \\
Batilembuti (QTb) a & Batulumpur & Akuifer tidak tertekan & 1,0 \\
Batilembuti (QTb) b & Marl/Batulumpur karbonat & Akuifer tidak tertekan & 1,0 \\
\hline Sumber: Analisis, 2020 & &
\end{tabular}




\section{Litologi Akuifer}

Parameter GOD kedua adalah Overall lithology of aquifer or aquitard ( $\mathrm{O}$ ) atau kondisi litologi akuifer secara keseluruhan (litologi akuifer) merupakan jenis material batuan dimana lapisan jenuh air yang dapat menyimpan dan melolosakan air (Lowrie \& William, 2007). Litologi akuifer diperoleh dari KESDM, (2015a) (Tabel 1) yang menyebutkan terdapat dua (2) tipe litologi akuifer, yaitu dengan penyusun berupa batugamping dan batuan padu. Litologi yang tersusun dari batugamping merupakan bagian dari Formasi Saumlaki (Qs) tersusun atas batuan batugamping koral, padat, setempat terbreksikan dengan keterusan ( $T$ ) sedang-tinggi KESDM (2015b). Karakteristik batuan dengan sisipan koral dan terdapat cangkang fosil memiliki sifat permeabilitas / kelulusan (K) tinggi, sehingga mempunyai potensi mengalirkan air di dalam rongga-rongga batuan dengan cepat yang dapat memicu percepatan terjadinya kerentanan pencemaran (Putranto et al., 2020). Berdasarkan karakteristik tersebut, pada material penysusun batugamping memiliki skor yang tinggi terhadap kerentanan, yaitu 0,8 (Tabel 3).
Secara umum litologi akuifer batugamping bagian dari Formasi Saumlaki (Qs) mendominasi di daerah penelitian, seperti yang disajikan secara keruangan (spasial) pada Gambar 6b. Penyusun litologi batuan padu merupakan bagian dari Formasi Batilembuti (QTb). Pada batuan padu Formasi Batilembuti (QTb) terdapat dua (2) nilai parameter akuifer yaitu nilai keterusan $(\mathrm{T})$ yang berbeda, yaitu zona a memiliki keterusan ( $T$ ) rendah dan zona $b$ rendah -sangat rendah (Tabel 4). Hal tersebut dipengaruhi oleh kondisi regional startigrafi proses pengendapan material sedimen, yaitu dengan penyusun perselingan batugamping pasiran, napal, batupasir gampingan pada zona a bagian QTb utara dan material napal, batugamping pada zona b bagian Qtb selatan (Gambar 2) (Sukardi \& Sutrisno, 1989). Berdasarkan klasifikasi skor litologi batuan padu, menurut Ferreira et al., (2004), litologi tersbut termasuk kelas yang tinggi dengan nilai skor 0,7. $\mathrm{Hal}$ tersebut dipengruhi oleh material penyusun utama yaitu batugamping dengan sifat keterusan (T) atau kemampuan mengalirkan air melalui bidang vertikal yang tinggi (Febriarta \& Larasati, 2020; Maino et al., 2019; Putranto \& Rüde, 2016).

Tabel 3. Penilaian Litologi Akuifer (O)

\begin{tabular}{lcllc}
\hline \multicolumn{1}{c}{ Formasi } & Batuan & Keterusan (T) & \multicolumn{1}{c}{ Litologi Akuifer } & Nilai/Skor \\
\hline $\begin{array}{l}\text { Saumlaki (Qs) } \\
\text { Batilembuti }\end{array}$ & Batugamping & Sedang-tinggi & $\begin{array}{l}\text { Batugamping koral, padat, setempat } \\
\text { terbreksikan }\end{array}$ & 0,8 \\
$\begin{array}{l}\text { (QTb) a } \\
\begin{array}{l}\text { Batilembuti } \\
\text { (QTb) b }\end{array}\end{array}$ & Batuan padu & $\begin{array}{l}\text { Rendah } \\
\text { Rendah-Sangat } \\
\text { rendah }\end{array}$ & $\begin{array}{l}\text { Perselingan batugamping pasiran, } \\
\text { Napal, batupasir gampingan }\end{array}$ & 0,7 \\
Napal, batugamping & 0,7 \\
\hline
\end{tabular}

Sumber: Analisis, 2020

\section{Kedalaman Muka Air Tanah}

Parameter kerentanan depth to groundwater table (D) atau kedalaman muka air tanah diperoleh dari pengukuran kedalaman air tanah dengan jumlah sampel 33 (Gambar 6c). Distribusi sampel pengukuran secara keruangan (spasial) dapat mewakili kondisi morfologi yaitu dataran pantai, morfologi bergelombang dengan kemiringan lereng miring hingga agak curan dan morfologi perbukitan yang berada di tengah Pulau Yamdena atau timur dari Kota Saumlaki (Gambar 6c).

Berdasarkan hasil pengukuran diketahui bahwa nilai kedalaman air tanah pada akuifer bebas (Tabel 4), maka kedalaman air tanah disebut dengan muka air tanah bebas atau muka freatik(Todd \& Mays, 2005). Kedalaman air tanah pada bagian pesisir dekat dengan garis pantai dengan morfologi datar hingga miring dengan kedalaman muka air tanah fretaik 0-2 m di bawah permukaan tanah. PUPR (2016) juga menyebutkan bahwa karakteristik sumber air baku menggunakan sumur dengan kedalaman dangkal 0-7 m dibawah permukaan laut di sepanjang Kota Saumlaki hingga di Pelabuhan Saumlaki. Pada morfologi bergelombang (bagian tengah Pulau Yamdena bagian selatan/bagian timur Kota Saumlaki) memiliki kedalaman muka air tanah freatik 2-18 m dibawah permukaan tanah. 
Hasil pengukuran kedalaman muka air tanah disajikan pada Tabel 4 dan secara keruangan (spasial) dilakukan interpolasi titik kedalaman menjadi kontur kedalaman air tanah (Gambar 4) dan dikelaskan setiap rentang kedalaman seperti yang disajikan pada Gambar 6c. Berdasarkan distribusi kedalaman muka air tanah freatik (Gambar 6c) menunjukkan posisi kedalaman air tanah yang relatif dangkal pada penggunaan lahan permukiman yang padat penduduk dengan rentang 0-2 $\mathrm{m}$ dibawah permukaan tanah.

Tabel 4. Penilaian Kedalaman Muka Air Tanah (D)

\begin{tabular}{cc}
\hline Kedalaman $(\mathrm{m})$ & Nilai/Skor \\
\hline$<2$ & 1,0 \\
$2-5$ & 0,9 \\
$5-10$ & 0,8 \\
$10-20$ & 0,7 \\
\hline
\end{tabular}

\section{Sumber: Analisis, 2020}

Kondisi kedalaman air tanah dengan rentang 0-2 $\mathrm{m}$ seperti di dataran pantai merupakan kedalaman yang sangat dangkal. Berdasarkan penilaian skor kerentanan <2 menurut Ferreira et al. (2004) nilai tersebut termasuk faktor kerentanan tinggi dengan nilai skor 1,0. Kedalaman air tanah freatik yang semakin dangkal memiliki potensi mengalirkan sumber pencemar (polutan) dengan jarak yang pendek sehingga memiliki waktu tempuh yang pendek atau singkat meresapkan sumber pencemar (polutan) ke sistem akuifer di dalam tanah. Sedangkan kondisi kedalaman yang semakin dalam akan memerlukan waktu untuk lebih lama untuk meresapkan sumber pencemar (polutan) kedalam sistem akuifer air tanah atau termasuk kerentanan rendah. Sehinga pada kedalaman 2-5 $\mathrm{m}$ hingga 10-20 m memiliki nilai skor kerentanan yang semakin kecil atau semakin tidak mempercepat proses kerentanan air tanah terhadap pencemaran (Devianto et al., 2019; Febriarta et al., 2020)
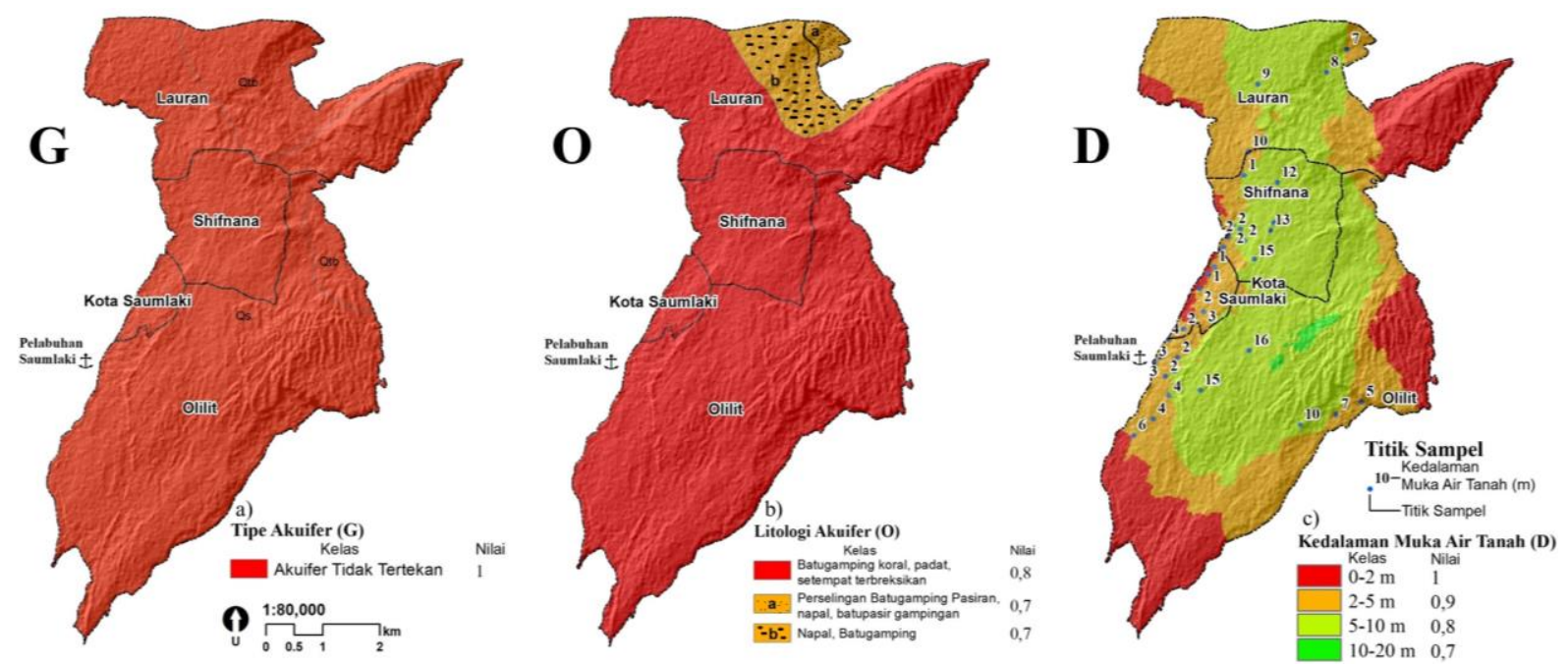

Gambar 6. Distribusi nilai skor setiap parameter GOD

\section{Validasi Kerentanan Dengan Kualitas Air}

Kualitas air tanah merupakan kondisi eksisting keadaan lingkungan (Balasubramanya \& Stifel, 2020). Parameter kualitas air tanah digunakan sebagai validasi hasil penilaian kerentanan air tanah terhadap pencemaran. Parameter nitrit $\left(\mathrm{NO}^{2}\right)$ merupakan salah satu sumber pencemar (pencemar) yang dapat menurunkan kualitas air yang bersumber dari sisa atau limbah domestik (rumah tangga) (Zulian et al., 2018)

Hasil analisis kualitas air tanah didasarkan atas nilai nitrit $\left(\mathrm{NO}^{2}\right)$ yang diukur oleh PUPR (2016) yang mengindikasikan bawa nitrit $\left(\mathrm{NO}^{2}\right)$ bersumber dari limbah domestik (rumah tangga). Kondisi nilai kualitas air tanah dari nilai nitrit $\left(\mathrm{NO}^{2}\right)$ disajikan pada Tabel 5. Seluruh sampel diambil pada penggunaan lahan permukiman (Gambar 3 dan Gambar 7).

Berdasarkan nilai konsentrasi nitrit $\left(\mathrm{NO}^{2}\right)$ lokasi K1 (Desa Lauran) berada pada batuan padu dengan nilai produktivitas kecil setampat kelulusan rendah menunjukkan nilai sebesar 1,11 mg/l, sedangkan sampel K2 dan K3 menunjukkan nilai yang lebih tinggi yaitu K2 sebesar 2,01 mg/l 
dan K3 sebesar 4,22 mg/l. Lokasi K1 secara litologi berada pada batulempung gampingan dengan indek kerentanan 0,7 dan lokasi sampek K2 san K3 berada pada litologi batugamping koral yang memiliki kerentanan 0,8 atau lebih tinggi. Secara kualitas kedua sampel K1 (1,11 mg/l) dan K2 (2,01 $\mathrm{mg} / \mathrm{l})$ tersebut masih berada di bawah nilai baku mutu yaitu $3 \mathrm{mg} / \mathrm{l}$, sedangkan sampel $\mathrm{K} 3(4,22$ $\mathrm{mg} / \mathrm{l})$ melebihi baku mutu air minum, yaitu $3 \mathrm{mg} / \mathrm{l}$ (PermenKes, 2010). Berdasarkan konsentrasi nilai nitrit $\left(\mathrm{NO}^{2}\right)$ memiliki korelasi bahwa pada daerah yang tingkat kerentanan yang tinggi menunjukkan nilai konsentrasi yang tinggi. Hal tersebut serupa dalam penelitian Voutchkova et al., (2021) dan Purnama \& Cahyadi (2019) dengan menggukan metode sifat hidrogeologis yang divalidasi dengan nilai nitrit $\left(\mathrm{NO}^{2}\right)$ yang tinggi pada zona kerentanan tinggi. Selain itu hasil penelitian menunjukan hasil yang serupa dengan Hosseini \& Saremi (2018) menyebutkan korelasi kerentanan tinggi dicirkan dengan nilai konsentrasi nitrat yang meningkat.

Tabel 5. Kualitas air tanah unsur nitrit $\left(\mathrm{NO}^{2}\right)$

\begin{tabular}{cccc}
\hline Kode & $\begin{array}{l}\text { Indek } \\
\text { Kerentanan }\end{array}$ & $\begin{array}{l}\text { Kerentanan } \\
\text { GOD }\end{array}$ & $\begin{array}{l}\text { Nitrit }\left(\mathrm{NO}^{2}\right) \\
(\mathrm{mg} / \mathrm{l})\end{array}$ \\
\hline $\mathrm{K} 1$ & 0,65 & Tinggi & 1,11 \\
$\mathrm{~K} 2$ & 0,8 & Ekstrim & 2,01 \\
$\mathrm{~K}^{*}$ & 0,8 & Ekstrim & 4,22 \\
\hline
\end{tabular}

*Keterangan: $\mathrm{K3}$ melebihi baku mutu $(3 \mathrm{mg} / \mathrm{l}$

PermenKes, 2010)

Sumber: PUPR, 2016 dan Analisis, 2020

\section{Analisis Kerentanan Air Tanah Terhadap Pencemaran}

Nilai indek kerentanan air tanah terhadap pencemaran diperoleh dari perhitungan linier (rumus 1) ketiga parameter kerentanan yaitu (Groundwater occurrence) atau kondisi keberadaan air tanah, O (Overall lithology of aquifer or aquitard) atau kondisi litologi akuifer atau akuitar secara keseluruhan, dan D (Depth to groundwater table) atau kedalaman muka air tanah freatik. Berdasarkan hasil perhitungan diketahui bawa nilai indek kerentanan air tanah terhadap pencemaran di Kota Saumlaki dan sekitarnya berkisar $0,65-0,8$. Kelas nilai tersebut termasuk kedalam dua (2) tingkat kerentanan, yaitu indek 0,65-0,7 tingkat kerentanan tinggi dan indek 0,7-0,8 tingkat kerenanan ekstrim (Gambar 7). Secara keruangan (spasial) tingkat kerentanan tinggi berada pada morfologi bergelombang dengan kemiringan lereng miring hingga agak curam yang berada di bagian tengah daerah penelitian. Sedangkan tingkat kerentanan air tanah terhadap pencemaran ekstrim terdistribusi mengelilingi daerah pesisir.

Zona dengan kerentanan tinggi dicirikan dengan tipe akuifer tidak tertekan (akuifer bebas), kondisi litologi akuifer berupa batugamping dan kedalaman muka air tanah 5-18m di bawah permukaan tanah. Peluang terjadinya pencemaran terhadap sumber pencemar (polutan) sebesar $50 \%$ dengan sifat menerus dan berulang. Zona dengan kerentanan ekstrim dicirikan dengan tipe akuifer tidak tertekan (akuifer bebas), kondisi akuifer berupa batugamping dengan media aliran rekah, celah dan pelarutan, dan kondisi kedalaman muka air tanah freatik $<2 \mathrm{~m}$ dibawah permukaan tanah. Peluang terjadinya pencemaran pada zona ektrsim dapat terjadi $>75 \%$ dari sumber pencemar (polutan). Hastuti et al. (2016) menyebutkan bahwa peluang terjadainya pencemaran pada tingkat kerentanan ekstrim dapat berlangsung dengan waktu yang cepat dan dapat tercemar oleh semua polutan.

Pada zona kerentanan tinggi, Desa Olilit memiliki zona kerentanan terluas yaitu $10,56 \mathrm{~km}^{2}$ atau seluas $25,38 \%$ dari luas daerah penelitain. Zona kerentanan tinggi dengan luas terkecil berada di sebagian Kota Saumlaki dengan luas wilayah sebesar $0,05 \mathrm{~km}^{2}$ atau $0,12 \%$ dari luas daerah penelitian. Pada zona kerentanan ektrim terluas berada di sebagian Desa Olilit dengan luas $29,23 \mathrm{~km}^{2}$ atau seluas $29,23 \%$ sedangkan wilayah dengan zona kerentanan ekrtim terkecil berada di sebagian Desa Sifnana yaitu $0,69 \mathrm{~km}^{2}$ atau seluas $1,66 \%$. Berdasarkan distribusi zona kerentanan, Kota Saumlaki memliki kerentanan ekstrim. Luas zona kerentanan air tanah terhadap pencemaran disajikan pada Tabel 6 dan distribusi secara keruangan (spasial) disajikan pada Gambar 7.

Tabel 6. Luas zona kerentanan air tanah terhadap pencemaran

\begin{tabular}{lcccc}
\hline \multirow{2}{*}{ Desa/Kelurahan } & \multicolumn{2}{c}{ Kerentanan Tinggi } & \multicolumn{2}{c}{ Kerentanan Ekstrim } \\
\cline { 2 - 5 } & $\mathrm{Km}^{2}$ & $\%$ & $\mathrm{Km}^{2}$ & $\%$ \\
\hline Saumlaki & 0,05 & 0,12 & 0,98 & 2,36 \\
Olilit & 10,56 & 25,38 & 12,16 & 29,23 \\
\hline
\end{tabular}

10| Geomedia : Majalah Ilmiah dan Informasi Kegeografian 


\begin{tabular}{lcccc}
\hline \multirow{2}{*}{ Desa/Kelurahan } & \multicolumn{2}{c}{ Kerentanan Tinggi } & \multicolumn{2}{c}{ Kerentanan Ekstrim } \\
\cline { 2 - 5 } & $\mathrm{Km}^{2}$ & $\%$ & $\mathrm{Km}^{2}$ & $\%$ \\
\hline Sifnana & 4,50 & 10,82 & 0,69 & 1,66 \\
Lauran & 5,13 & 12,33 & 7,53 & 18,10 \\
Total & 20,24 & 48,65 & 21,36 & 51,35 \\
\hline
\end{tabular}

Sumber: Analisis, 2020

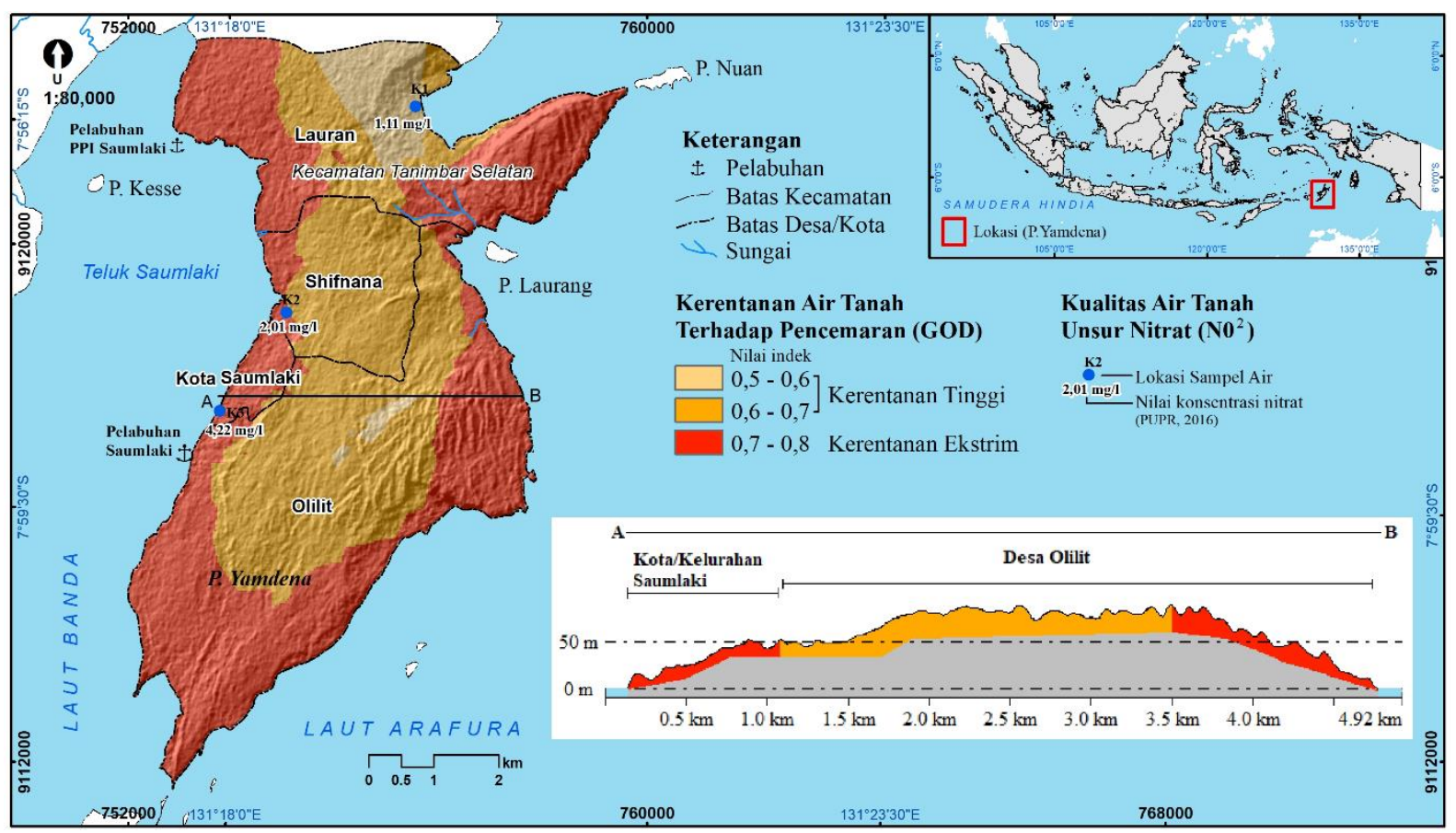

Gambar 7. Tingkat kerentanan air tanah terhadap pencemaran termasuk tinggi dan ekstrim

\section{Simpulan dan Saran}

Nilai indek kerentanan air tanah terhadap pencemaran sebesar $0,65-0,8$, nilai tersebut termasuk pada tingkat kerentanan tinggi dan kerentanan ekstrim. Faktor yang mempengaruhi hal tersebut dalah tipe akuifer tidak tertekan (akuifer bebas), litologi akuifer berupa batugamping dengan sifat kelulusan $(\mathrm{K})$ yang tinggi sehingga memicu percepatan pencemaran dari sumber pencemar (polutan). Metode GOD telah membuktikan bahwa pemodelan kerentanan air tanah dapat diaplikasikan dengan parameter akuifer sesuai dengan kondisi litologi (geologi) yang berbeda dari jenis akuifer dengan keterbatasan data. Secara umum metode GOD didasarkan atas sifat perkolasi vertikal terhadap batuan diatas zona tak jenuh, dan belum mempertimbangkan pemicu pencemaran seperti faktor curah hujan.

Saran yang dapat diberikan dalam pengelolaan air tanah pada zona kerentanan tinggi adalah dengan pembuatan saluran sanitasi yang terpadu, pengelolaan sampah yang terpadu, dan edukasi tentang limbah domestik (rumah tangga). Sedangkan saran yang dapat diberikan pada zona kerentanan ekstrim adalah dengan pemantauan sumber air secara berkala dan diuji kualitas air berdasarkan baku mutu dan dengan pembuatan undangundang perlindungan dan pengelolaan lingkungan hidup oleh pemerintah daerah.

\section{Ucapan terima kasih}

Artikel ini merupakan analisis lanjut dari kajian Pemetaan Karakteristik dan Ekosistem Pesisir Maluku yang difasilitasi oleh Badan Informasi Geospasial (BIG) Republik Indonesia. Ucapan terima kasih disampaikan kepada Badan Informasi Geospasial (BIG) Republik Indonesia yang telah memfasilitasi dan mendukung penelitian ini

\section{Referensi}

Abdelmadjid, B., \& Omar, S. (2013). Assessment of groundwater pollution by nitrates using intrinsic vulnerability methods: A case study of the Nil valley groundwater (Jijel, North-East Algeria). African Journal of 
Environmental Science and Technology, 7(10), 949-960.

Akhtar, M., Zhao, Y., Gao, G., Gulzar, Q., Hussain, A., \& Samie, A. (2020). Assessment of ecosystem services value in response to prevailing and future land use/cover changes in Lahore, Pakistan. Regional Sustainability, 1(1), 37-47. https://doi.org/10.1016/j.regsus.2020.06. 001

Aller, L., Bennett, T., Lehr, J. H., Petty, R. J., \& Hackett, G. (1987). DRASTIC; a Standardized System for Evaluating Ground water Pollution Potential Using Hydrogeologic Settings. United States Environmental Protection Agency. http://cfpub.epa.gov/si/ntislink.cfm?dirEn tryID $=35474$

Balasubramanya, S., \& Stifel, D. (2020). Viewpoint: Water, agriculture \& poverty in an era of climate change: Why do we know so little? Food. Policy, 93(1), 1-10.

BSN. (2002). Standar Nasional Indonesia No. 196728.1-2002 Penyusunan Neraca Sumber Daya - Bagian 1: Sumber Daya Air Spasial. Badan Standardisasi Nasional. In Badan Standardisasi Nasional (BSN): Vol. ICS 13.060. Badan Standardisasi Nasional (BSN).

BSN. (2005). Standar Nasional Indonesia (SNI) no.13-1712-2005 tentang penyelidikan potensi air tanah skala 1:100.000 atau lebih besar. Badan Standardisasi Nasional (BSN).

BSN. (2012). Standar Nasional Indonesia (SNI) 2528:2012 Tata Cara Pengukuran Geolistrik Schlumberger Untuk Eksplorasi Air Tanah. Badan Standarisasi Nasional. http://sni.litbang.pu.go.id/image/sni/isi/s ni-28182012.pdf

Cahyadi, A. (2019). Analisis Kerentanan Airtanah terhadap pencemaran di Pulau Koral Sangat Kecil dengan Menggunakan Metode GOD. Jurnal Geografi, 16(1), 4853.

Ciemens, M., Khurelbaatar, G., Merz, R., Siebert, C., Affeden, M. V, \& Rodiger, T. (2020). Groundwater Protection Under Water Scarcity; From Regional Risk Assessment To Local Wastewater Treatment Solutions In Jordan. Science of The Total Environment, 7(1), 1-13.
Devianto, L. A., Lusiana, N., \& Ramdani, F. (2019). Analisis Kerentanan Pencemaran Air Tanah di Kota Batu Menggunakan Analisis Multikriteria Spasial dengan Indeks DRASTIC. Jurnal Wilayah Dan Lingkungan, $7(2), \quad 90-104$. https://doi.org/10.14710/jwl.7.2.90-104

DPU. (1996). Standar Kebutuhan Air Rumah Tangga. Pengembangan Kawasan Perkotaan, Kawasan Perdesaan Dirjen Pekerjaan Umum.

ESDM. (1995). Produktivitas Akuifer. Energi dan Sumber Daya Mineral (ESDM).

Febriarta, E., Argadyanto, B. ., \& Rosaji, F. S. candra. (2018). Sumber Daya Air di Pulau Pelapis Kepuluan Karimata kabupaten Kayong Utara. Prosiding Seminar Nasional-4 Pengelolaan Pesisir Dan Daerah Aliran Sungai., 4, 181-186. https://doi.org/10.17605/osf.io/ezhdt.

Febriarta, E., Haryono, E., \& Adji, T. N. (2015). Aplikasi Teknologi Isotop Alam untuk Menentukan Asal Usul Airtanah Pesisir. Seminar Nasioan Pengelolaan Pesisir Dan Daerah Aliran SUngai Ke-1, 1, 100-105. https://doi.org/https://doi.org/10.17605/ osf.io/7a5m6

Febriarta, E., \& Larasati, A. (2020). Karakteristik Akuifer Air Tanah Dangkal Di Endapan Muda Merapi Yogyakarta. Jurnal Sains Dan Teknologi Lingkungan, 12(2), 84-99. https://doi.org/https://doi.org/10.20885/j stl.vol12.iss2.art1

Febriarta, E., Marfai, M. A., Hizbaron, D. R., \& Larasati, A. (2020). Kajian Spasial Multi Kriteria DRASTIC Kerentanan Air tanah Pesisir Akuifer Batugamping di Tanjungbumi Madura. Jurnal IImu Lingkungan, 18(3), 476-487. https://doi.org/10.14710/jil.18.3.476-487

Febriarta, E., \& Oktama, R. (2020). Pemetaan Daya Dukung Lingkungan Berbasis Jasa Ekosistem Penyedia Pangan Dan Air Bersih Di Kota Pekalongan. Jurnal Ilmu Lingkungan, 18(2), 283-289. https://doi.org/10.14710/jil.18.2.283-289

Febriarta, E., \& Widyastuti, M. (2020). Kajian Kualitas Air Tanah Dampak Intrusi Di Sebagian Pesisir Kabupaten Tuban. Jurnal Geografi: Media Informasi Pengembangan Dan Profesi Kegeografian, 17(2), 39-48. 
https://doi.org/10.15294/jg.v17i2.24143

Ferreira, J. P., Lobo, Oliveira, \& Manuel, M. (2004). Groundwater Vulnerability Assessment in Portugal. Geofisica International, 4, 541-550.

Fetter, C. W. (2014). Applied Hydrogeology. Pearson New Internasional Edition.

Foster, S. S. . (1987). Fundamental Concepts in Aquifer Vulnerability, Pollution Risk and Protection Strategy, Vulnerability of Soil and Groundwater to Pollutants. TNO Commission on Hydro Res, 38, 69-86.

Guettaia, S., Hacini, M., Boudjema, A., Zahrouna, A., Boudjema, A., \& Ferrão, P. (2017). Vulnerability assessment of an aquifer in an arid environment and Vulnerability assessment of an aquifer in an arid environment and comparison of the applied methods: case of the mio-plioquaternary comparison of the applied methods: case of the mio-pli. Energy Procedia, 119, 482-489. https://doi.org/10.1016/j.egypro.2017.07. 057

Hastuti, D., Yulianto, T., Putranto, T. T., Fisika, D., Diponegoro, U., Geologi, D. T., Teknik, F., \& Diponegoro, U. (2016). Dataran Alluvial Kota Semarang Menggunakan Metode God Dengan Memanfaatkan Data Resistivitas Dan Data. Youngster Physics Journal, 5(4), 277-290.

Hosseini, M., \& Saremi, A. (2018). Assessment and Estimating Groundwater Vulnerability to Pollution Using a Modified DRASTIC and GODS Models (Case Study: Malayer Plain of Iran). Civil Engineering Journal, 42(2), 433-422.

KESDM. (2012). Geologi. Kementerian Energi dan Sumber Daya Mineral. https://geoportal.esdm.go.id/geologi/

KESDM. (2015a). Litologi Akuifer. Kementerian Energi dan Sumber Daya Mineral. https://geoportal.esdm.go.id/geologi

KESDM. (2015b). Produktivitas Akuifer. Kementerian Energi dan Sumber Daya Mineral.

https://geoportal.esdm.go.id/geologi/

KESDM. (2018a). Cekungan Air Tanah (CAT). Kementerian Energi dan Sumber Daya Mineral.

https://geoportal.esdm.go.id/geologi/

KESDM. (2018b). Kawasan Bentang Alam karst
(KBAK). Kementerian Energi dan Sumber Daya Mineral.

Kohfahl, C., Molano-Leno, L., Martínez, G., Vanderlinden, K., Guardiola-Albert, C., \& Moreno, L. (2019). Determining groundwater recharge and vapor flow in dune sediments using a weighable precision meteo lysimeter. Science of The Total Environment, 656, 550-557. https://doi.org/10.1016/j.scitotenv.2018.1 1.415

Linggasari, S., Cahyadi, T. ., \& Ernawati, R. (2019). Overview Metode Perhitungan Kerentanan Airtanah Terhadap Rencana Penambangan. Prosiding Nasional Rekayasa Teknologi Industri Dan Informasi XIV Tahun 2019 (ReTII)., 14, 123129.

Lowrie, \& William. (2007). Fundamental of Geophysics. Cambridge University Press.

Maino, P. A., Manu, E., Yidana, S. M., Agyekum, W. A., Stiger, T., Duah, A. A., \& Preko, K. (2019). Application of 2D-Electrical resistivity tomography in delineating groundwater potential zones: Case study from the voltaian super group of Ghana. Journal Of African Earth Sciences, 160(1), $1-12$.

Milsom. (2003). Field Geophysics, The Geological Field Guide Series (3rd ed.). West Sussex: John Wiley \& Sons.

Permen ESDM. (2012). Peraturan Menteri ESDM No. 17 Tahun 2012 Tentang Penetapan Kawasan Bentang Karst. Menteri Energi dan Sumber Daya Mineral.

PermenKes. (2010). Peraturan Menteri Kesehatan Republik Indonesia No 492/Menkes/Per/IV/2010: Persyaratan Kualitas Air Minum. Peraturan Menteri Kesehatan Republik Indonesia.

PUPR. (2016). Penyusunan Rencana Induk Sistem Pelayanan Air Minum (RI-SPAM) Kabupaten Maluku Tenggara Barat. Direktorat Jendral Cipta Karya Kementerian Pekerjaan Umum dan Permukiman Rakyat.

Purnama, S., \& Cahyadi, A. (2019). Groundwater Vulnerability to Pollution in Kasihan District, Bantul Regency, Indonesia. Forum Geografi $\quad 33(2)$, 140-152. https://doi.org/10.23917/forgeo.v33i2.76 72 
Putranto, T. T. (2019). Studi Kerentanan Airtanah Terhadap Pencemaran Dengan Menggunakan Metode Drastic Pada Cekungan Airtanah (CAT) KaranganyarBoyolali, Provinsi Jawa Tengah. Jurnal I/mu Lingkungan, 177(1), 159. https://doi.org/10.14710/jil.17.1.159-171

Putranto, T. T., \& Rüde, T. (2016). Hydrogeological Model of an Urban City in a Coastal Area, Case study: Semarang, Indonesia. Indonesian Journal on Geoscience, $3(1)$. https://doi.org/10.17014/ijog.3.1.17-27

Putranto, T. T., Winarno, T., \& Susanta, A. P. A. (2020). Risk Assessment of Groundwater Abstraction Vulnerability Using Spatial Analysis: Case Study at Salatiga Groundwater Basin, Indonesia. Indonesian Journal on Geoscience, 7(2). https://doi.org/10.17014/ijog.7.2.215-224

Rathinasamy, M., Chandramouli, S., Phanindra, K. B. V. N., \& Mahesh. (2019). Water Resource and Enviromental Enginering I: Surface and Groundwater. Springer.

Setyaningrum, A., \& Febriarta, E. (2019). Analisis Kesesuaian dan Daya Dukung Ekowisata Pantai Kategori Rekreasi Pantai Kuwaru Kabupaten Bantul Yogyakarta. Seminar Nasional Pengelolaan Pesisir Dan Daerah Aliran Sungai Ke-5, 5(March), 36-41. https://doi.org/https://doi.org/10.17605/ OSF.IO/82PTU

Singhal, B. B. ., \& Gupta, R. . (2010). Applied Hydogeology of Fracture Rock. Springer Dordrecht Heidelberg London.

Siswoyo, H. (2018). Identifikasi Tingkat Kerentanan Akuifer Terhadap Pencemaran di Kecamatan Sumobito Kabupaten Jombang Dengan Menggunakan Metode GOD. Jurnal Sains Dan Edukasi Sains, 1(2), 1-6.

Sukardi, \& Sutrisno. (1989). Peta Geologi Lembar Kepulauan Tanimbar, Maluku. Pusat Penelitian dan Pengembangan Geologi.

Telford, W. M., Geldart, L. P., \& Sheriff, R. E. (1990). Applied Geophysics (Second Edi). Cambridge University.

Todd, D. K., \& Mays, L. W. (2005). Groundwater Hydrology (3rd ed.). John Wiley \& Sons, Inc.

Uhlemann, S., Kuras, O., Richards, L. A., Naden,
E., \& Polya, D. A. (2017). Electrical resistivity tomography determines the spatial distribution of clay layer thickness and aquifer vulnerability, Kandal Province, Cambodia. Journal of Asian Earth Sciences, 147, 402-414. https://doi.org/10.1016/j.jseaes.2017.07.0 43

Vienastra, S., \& Febriarta, E. (2018). Karakteristik Airtanah di Pulau Yeben, Kabupaten Raja Ampat, Papua Barat. Prosiding Pertemuan IImiah Tahunan Ke-3 Perhimpunan Ahli Airtanah Indonesia, 3(November), 108113.

https://doi.org/https://doi.org/10.17605/ OSF.IO/EZHDT

Voutchkova, D. D., Schullehner, J., Rasmussen, P., \& Hansen, B. (2021). A high-resolution nitrate vulnerability assessment of sandy aquifers (DRASTIC-N). Journal of Environmental Management, 277, 111330. https://doi.org/10.1016/j.jenvman.2020.1 11330

Vrba, J., \& Zaporozec, A. (1994). Guidebook on Mapping Groundwater Vulnerability. International Association of Hydrogeologist.

Zulian, G., Stange, E., Woods, H., Carvalho, L., Dick, J., Andrews, C., Baró, F., Vizcaino, P., Barton, D. N., Nowel, M., Rusch, G. M., Autunes, P., Fernandes, J., Ferraz, D., Ferreira dos Santos, R., Aszalós, R., Arany, I., Czúcz, B., Priess, J. A., ... Viinikka, A. (2018). Practical application of spatial ecosystem service models to aid decision support. Ecosystem Services, 29, 465-480. https://doi.org/10.1016/j.ecoser.2017.11.0 05 